\title{
Power Flow Study on Container Crane with Simulation-Based Renewable Energy Supply
}

\author{
Dodi Fasha ${ }^{1}$ and Sardono Sarwito ${ }^{2}$ \\ (Received: 22 August 2020 / Revised: 10 December 2020 / Accepted: 12 December 2020)
}

\begin{abstract}
However, currently, several container ports are implementing an eco-friendly port (green port) concept. Renewable natural resources, such as the sun's heat energy, are used as an alternative to supports the green port concept. Container cranes, the main heavy equipment in the loading and unloading processes, are generally supplied with electricity from PLN and diesel generators. In this research, it was tried by modeling container crane's one-line diagram into ETAP, but by adding renewable energy resources simulation, such as solar panels. Solar panel's characteristics, such as voltage and output frequency are different from PLN and diesel generators. Then, the difference results will be analyzed. After the simulation, results in comparison, known that solar panels can be used for container crane's electrical system supply. In this study, the PV's inverter output voltage is 0.38 kilo-volt. The PV supply simulation results in lower power efficiency and higher voltage drop than the PLN and diesel generator's supply. As for each PV supply scenario, power efficiency and drop voltages are still within the IEC and IEEE standard limits. For example, in the gantry scenario, the power efficiency is $94.44 \%$, and the drop voltage is $0.274 \%$.
\end{abstract}

Keywords—container crane, ETAP, load flow, solar panel.

\section{INTRODUCTION}

$\mathrm{P}$ ort is an industrial area that is linked with loading and unloading activities, its cargo type like bulk, or in packaging, or in containers. This routine activity that takes place every day makes the port seem like it never stops conducting trading activities and transportation of cargo from ships to dock, and so on. This also makes porting play an important role in marine pollution and air pollution. Based on their pollution caused, a new concept has emerged, namely the Green Port concept. The concept of 'Green Port' is a concept that is become part of the commitment of ports in the world to reduce carbon emissions.

Datuk Abdul Rahim, Chairman of The $32^{\text {nd }}$ Asean Port Association Working Committee (APA WCM), emphasized that the green port concept must be implemented by the ports that are members of the IMO (International Maritime Organization), the concept of green ports is one of the concepts approved by ports in the world in reducing carbon emissions, as well as providing incentives for ships that do not throw garbage and reduce oil consumption. The port can also take benefit from this clean environment. Another thing that is prioritized in the development of green ports is the ability of ports to master information and communication technology, this is done so that work in the port area becomes more effective and efficient, which results in cutting ship waiting times so that services are better. Currently, the green port concept has been implemented in several national and international ports in Indonesia. One of them is Pelindo III's container port, PT. Terminal Teluk Lamong. PT. Terminal Teluk Lamong (PT.TTL) is a terminal built by Pelindo III. Located north of Surabaya, PT. TTL was inaugurated in 2015 by President Jokowi as the Greater Surabaya Metropolitan Port' or

Dodi Fasha, Department of Marine Engineering, Institut Teknologi Sepuluh Nopember, Surabaya, 60111, Indonesia. E-mail: fashadodi@gmail.com

Sardono Sarwito, Department of Marine Engineering, Institut Teknologi Sepuluh Nopember, Surabaya, 60111, Indonesia. E-mail: sarsar@its.ac.id
GSMP, which is specific to the deepening and widening of the Surabaya West Shipping Channel (APBS) carried out by Pelindo III. As the first container terminal in Indonesia to apply semi-automatic technology as a green port concept, PT. TTL has 1 domestic dock and 1 international dock, as well as several heavy types of equipment powered by electricity and gas, including CNG (Compressed Sodium Gas) trucks, Automated Stacking Crane (ASC), Ship to Shore (STS) Container Crane, Combined Terminal Tractor (CTT) and Docking System, Grab Ship Unloader (GSU), Conveyor, to Gas Engine Power Plant (PLTMG). 10 STS Container Crane owned by PT. TTL is a facility that always operates every day.

The flow of load and power in each electric motor of the STS container crane electrical system must be good and based on specifications of its tool, in order to minimize the possibility of damage to the STS container crane electrical system. Therefore, this research requires a study related to the flow of power from the power supply of PT. TTL towards the load contained in each electric motor per STS container crane. In general, the electric motor supply in each crane uses an AC voltage supply from PLN and an AC generator, but in this study an experiment was carried out with a DC voltage supply made from solar heat power, namely using a solar-cell component. The load-flow analysis is more focused on knowing the amount of power flow of the solar-cell power source to the electric motor load in the container crane electrical system, is it stable, optimal, and has met the applicable minimum limit standards (IEC and IEEE). In addition, the benefits of this power flow study are also to determine the ratio of power losses and voltage drops from each simulation, be it AC supply voltage or DC current voltage. The purpose of this research is: knowing the value of active power, reactive power, power loss, and voltage drop in each operation of the main motor of STS container crane with ETAP modeling software, knowing the comparison of each simulation experiment between AC current supply voltage from PLN \& generator and DC current voltage supply from solar-cell 
on STS container crane with ETAP modeling software, last, knowing the power flow and the results of the comparison of the supply voltage in the scenario when

\section{METHOD}

\section{A. Problem Identification and Formulation}

The initial steps taken in conducting research for this final project is to read the final report according to the field of study and look for things in the research that can be developed or researched better. The researcher took a problem formulation regarding the power flow study, which was carried out using modeling in simulation software, especially for case studies on the ship-to-shore container crane's electrical system.

\section{B. Study of Literature}

For the literature study stage, it is carried out by finding and collecting information and theories about the flow of power in an electrical object in the maritime world, namely the container crane. Some of these theories and information and theories are found in offline and online media, such as journals, final project archives, books, to the internet.

All references and literature such as journals and books related to the making of this final project can be searched in several places such as MEAS (Marine Electrical and Automation System) Laboratory belonging to the Department of Marine Engineering FTK-ITS, FTK-ITS Reading Room, and ITS Library.

\section{Searching and Collecting Data}

At this stage, several activities were carried out whose main purpose was to collect primary data from the object of the final project research, especially in the case of the power flow study in this simulation-based container crane, some of the data obtained included:

1. STS-01 container crane specification data of PT. Teluk Lamong Terminal, and

\section{RESULTS AND DISCUSSION}

\section{A. Search and Collecting Data}

In the search and collection stage, it was carried out by looking for data directly from the STS-01 container crane owned by PT. Teluk Lamong Terminal. The data includes the specifications of the container crane, both mechanical and electrical. Data and specifications related to the electrical field of container cranes consist of electrical specifications for each main electric motor of the container crane (gantry, boom, hoist, trolley), transformers that supply container cranes, and several other electrical components as well as single-line both hoist and trolley motors are operated simultaneously.

\section{Single-line diagram data of STS-01 container crane.}

\section{Making Container Crane's One-Line Diagram}

At this stage, a one-line container crane diagram series was made from official data belonging to PT. Teluk Lamong Terminal, using the ETAP application.

\section{E. Simulation}

At the simulation stage, the one-line diagram of the electrical system container crane ETAP is executed according to the scenario of each electric motor load, as well as each AC and DC voltage supply, on the predetermined container crane.

\section{F. Data Simulation Recapitulation}

The simulation stage has been completed, then it is followed by recording each power flow, such as the value of active power, reactive power, apparent power, electric current, to the power factor displayed on the ETAP.

\section{G. Analysis of Results and Discussion}

At this stage, after the data for each simulation is recorded, the simulation data will be matched or validated with the applicable rules or standards (IEEE and IEC standards). Also, if the simulated electrical system does not meet it, efforts will be made to repair it, which will also be discussed at this stage.

\section{H. Conclusions and Recommendations}

At this final stage, the final research project has been completed. After that, several conclusions were made from all the discussions contained in this final project, as well as suggestions related to the research results of this final project, so that later they could become further studies that could be further developed.

diagrams of one. container crane as a whole. The data will then be modeled through a simulation application.

\section{B. Container Crane STS-01 Teluk Lamong Terminal's One-line Diagram}

At this stage, after obtaining sufficient data and specifications from the object, it is continued to read the single-line container crane STS-01 diagram belonging to PT. Lamong Bay Terminal. After that, the diagram is modeled through the ETAP simulation application. As for an example of the display of the original electrical circuit rather than the container crane diagram STS-01 belonging to PT. Teluk Lamong Terminal is shown in Figure 1. 


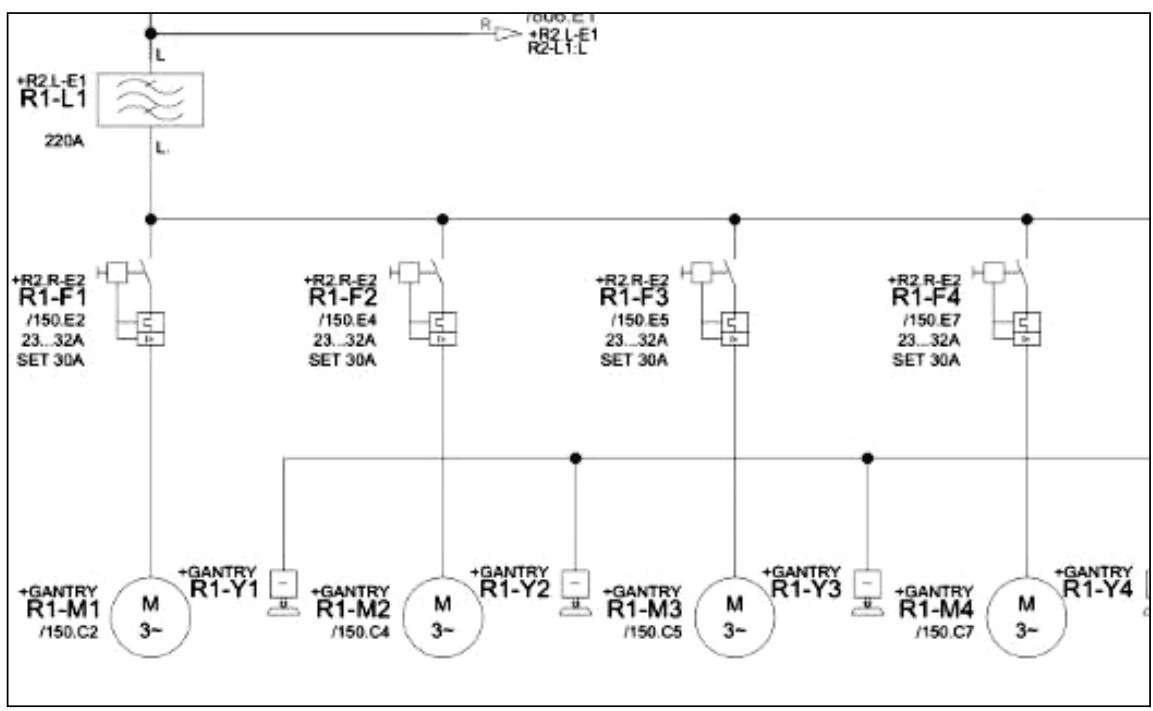

Figure. 1. Example of STS-01 container crane's one-line diagram

C. STS-Container Crane Simulation Scenario Planning

In the simulation scenario planning stage, after the circuit is modeled in ETAP, there is a supply section and an electrical load section that will be used as modeling with several scenarios. In the system, the main power supply is electricity from the PLN grid in swing mode and there are 2 generators in standby voltage control mode. Before heading to the load, the system is installed with a step-down transformer to suit the electrical loads. Then, the PV supply also consists of 4 PV Array (1 PV Array contains 4 panels) [9]. As for the example specifications and detailed modeling schemes in this part of the supply, it can be shown in Figure 2-4.

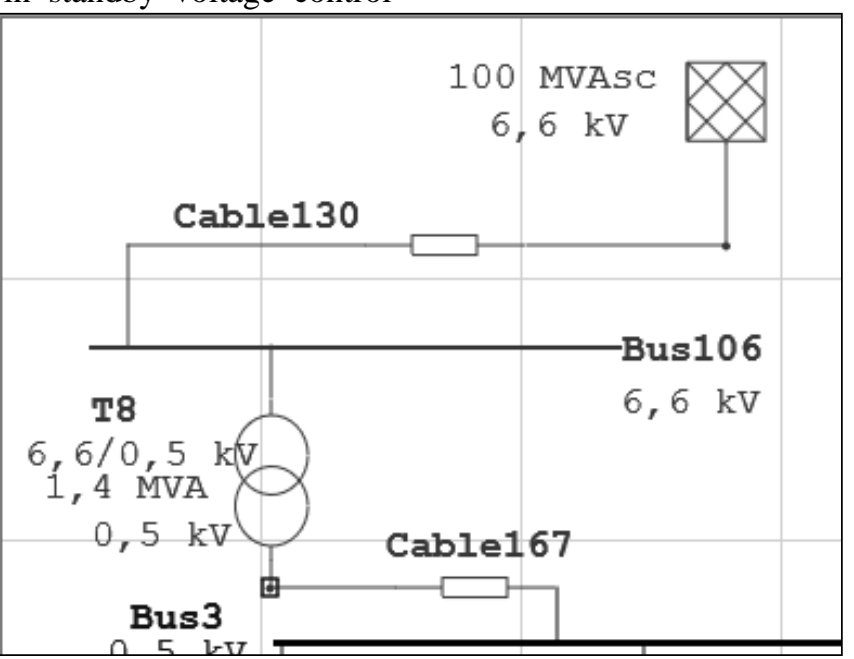

Figure. 2. Display of PLN and the main transformer of the container crane on the ETAP

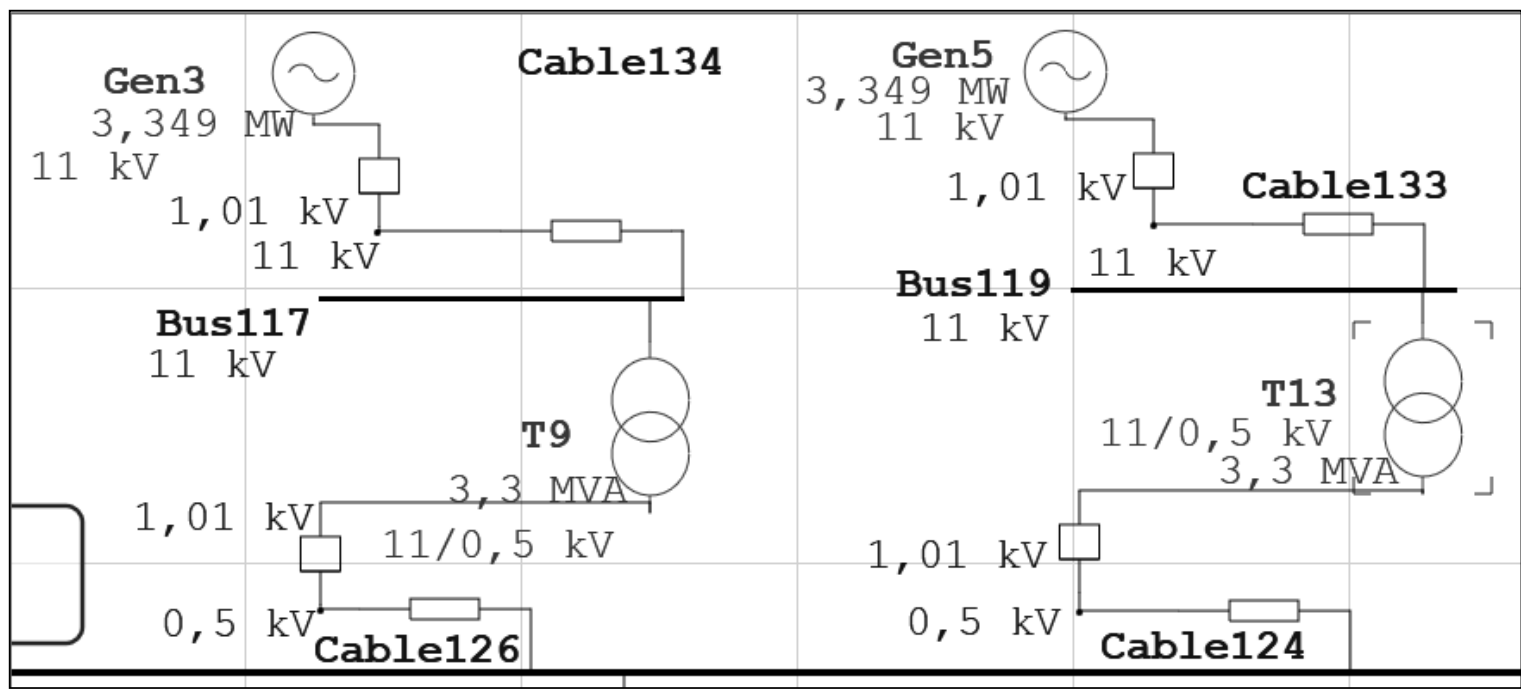

Figure. 3. Display of generators (voltage control) of the container crane on the ETAP 


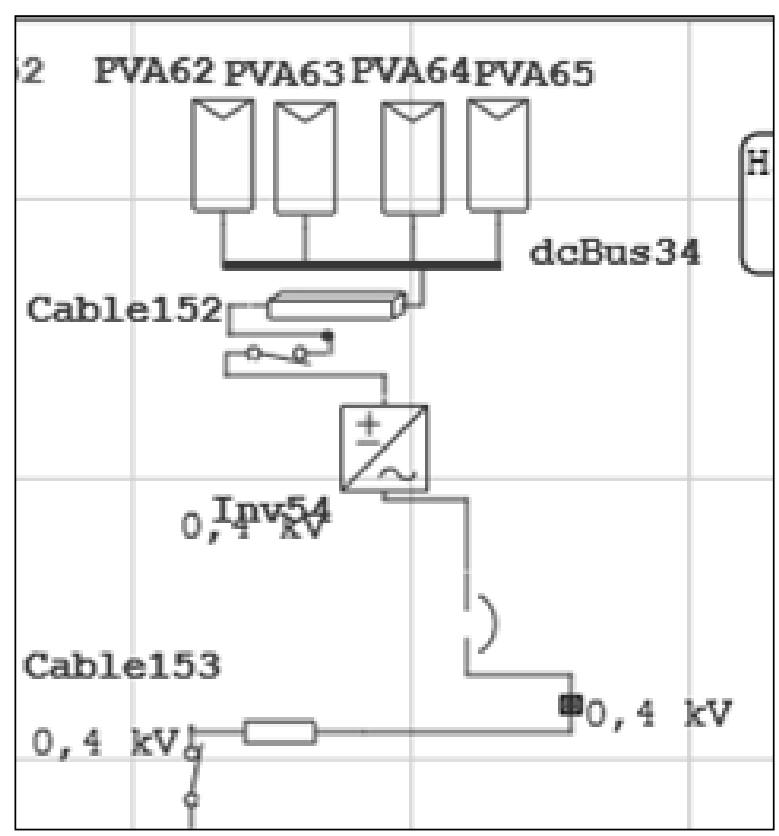

Figure. 4. Display of solar-cell of the container crane on the ETAP

\section{Gantry Motor}

As for the depiction of the location of the gantry motor on the ETAP, it is shown in Figure 5 for the seaside gantry motorbike and 6 for the landside gantry motor.

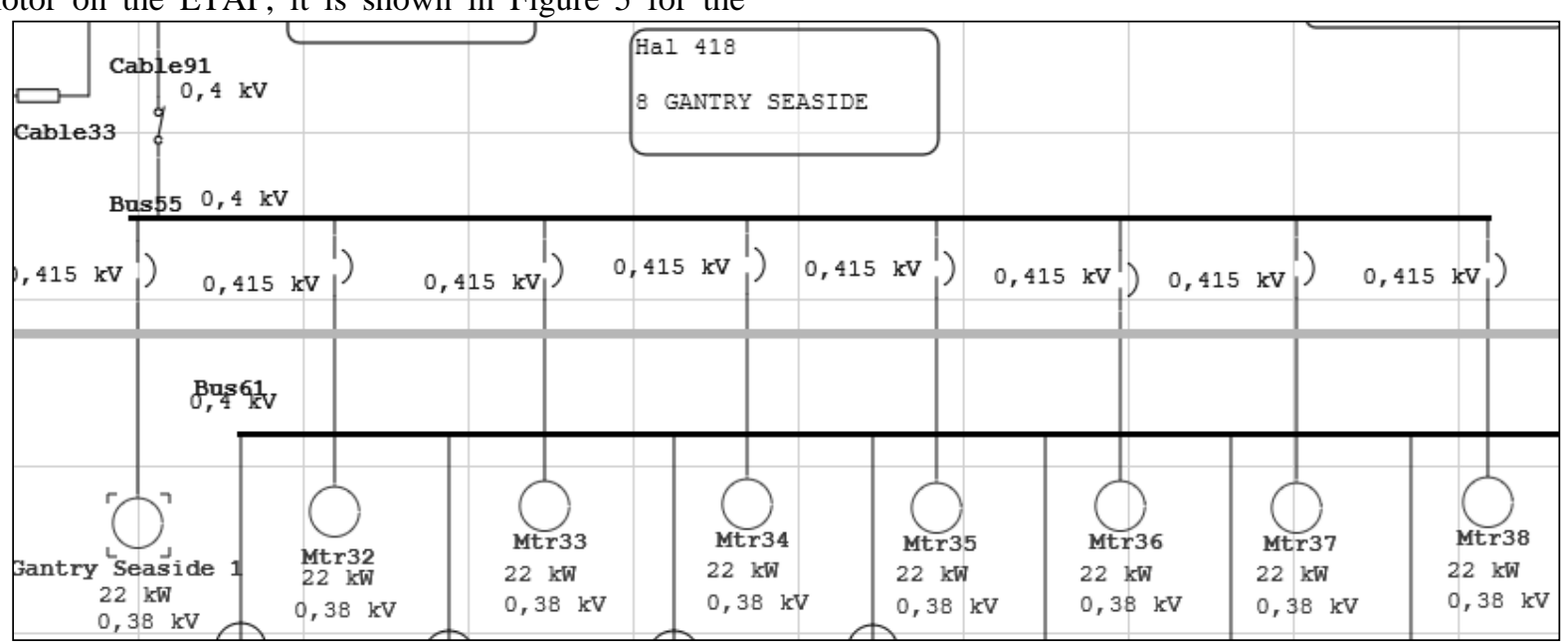

Figure. 5. Display of seaside gantry motor of the container crane on the ETAP

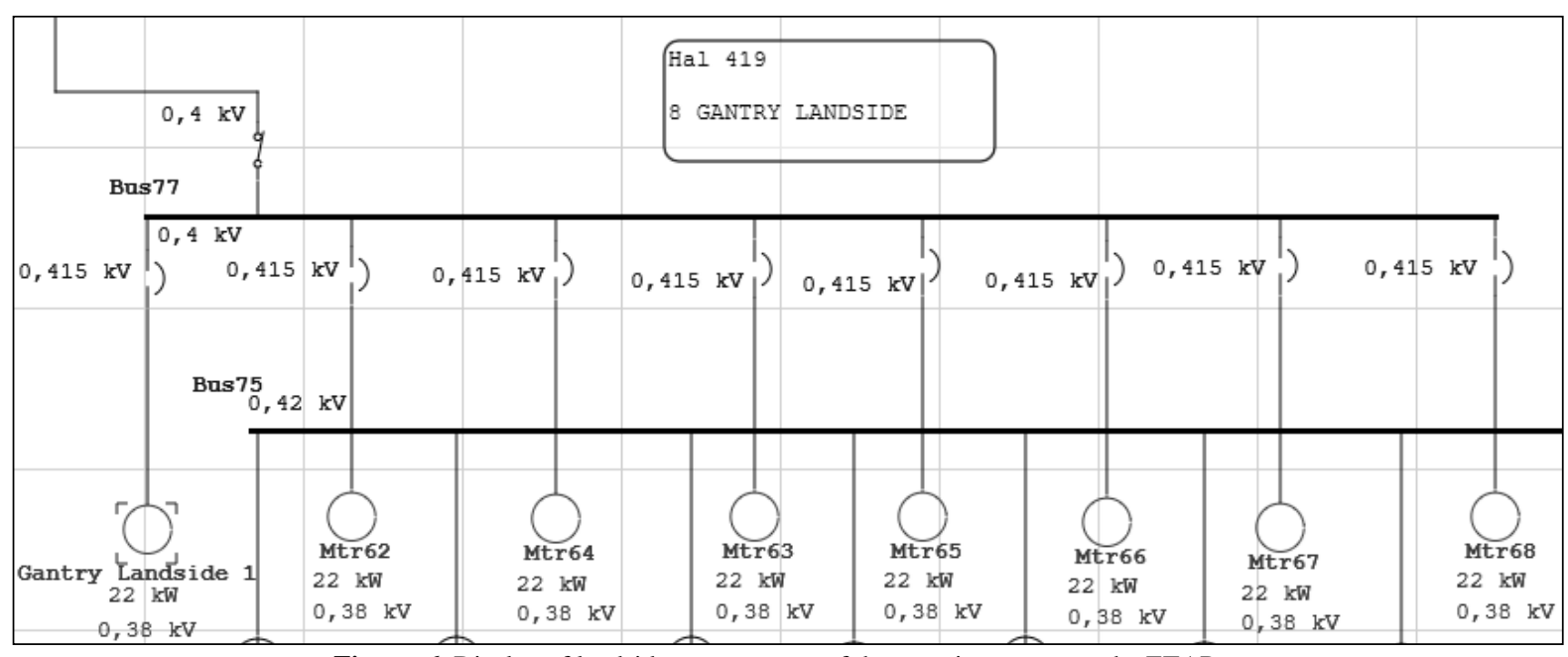

Figure. 6. Display of landside gantry motor of the container crane on the ETAP 
2. Boom Motor the motor on the ETAP is shown in Figure 7 below.

As for the depiction of the location of the boom

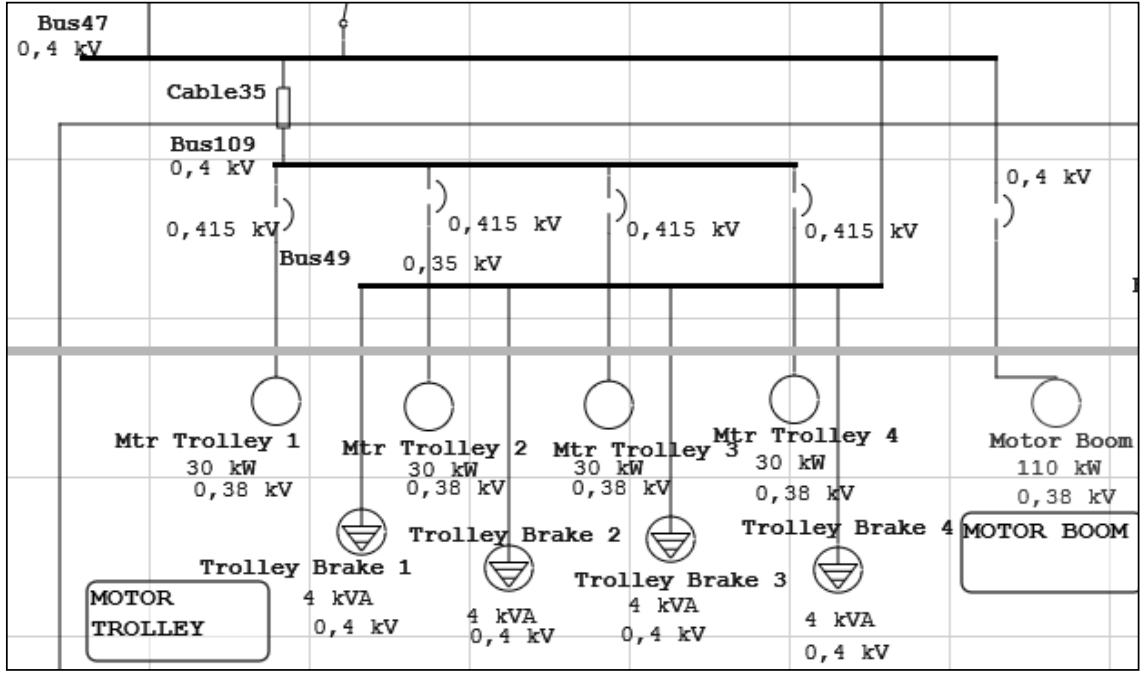

Figure. 7. Display of boom motor of the container crane on the ETAP

3. Trolley Motor after being modeled on the ETAP, it is shown in Figure 8.

Meanwhile, for the display including the location of the trolley motor

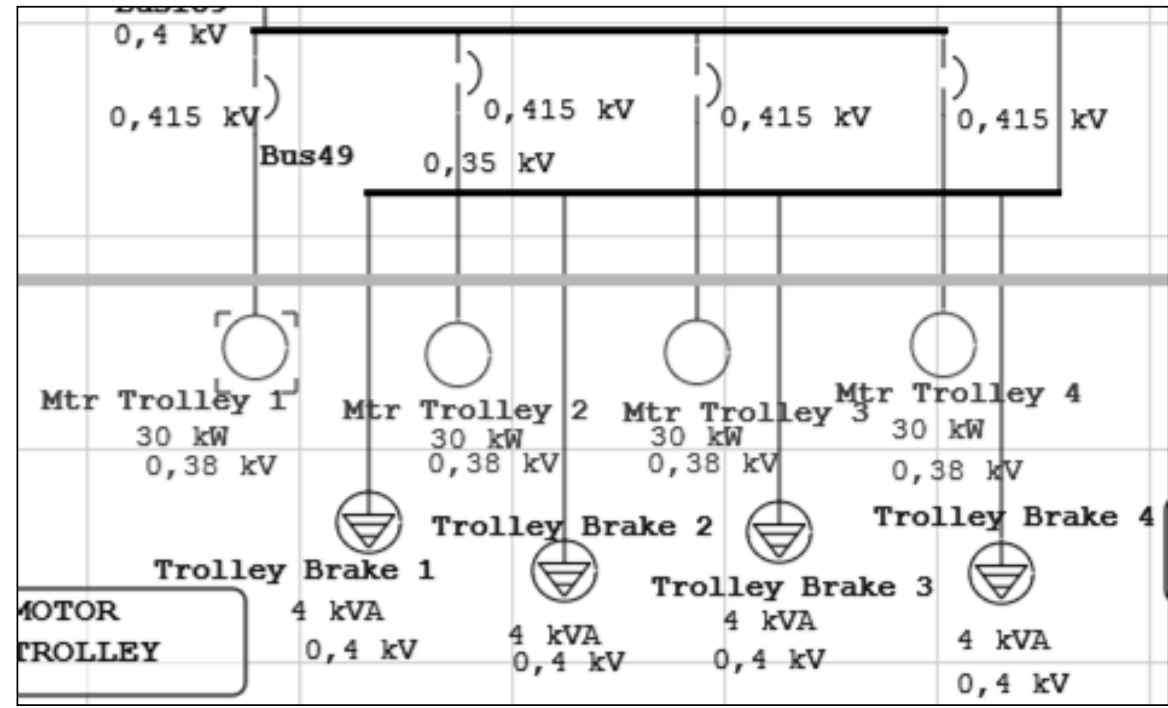

Figure. 8. Display of trolley motor of the container crane on the ETAP.

\section{Hoist Motor}

Meanwhile, for the display including the location of the hoist motor after being modeled on the ETAP, it is shown in Figure 9 


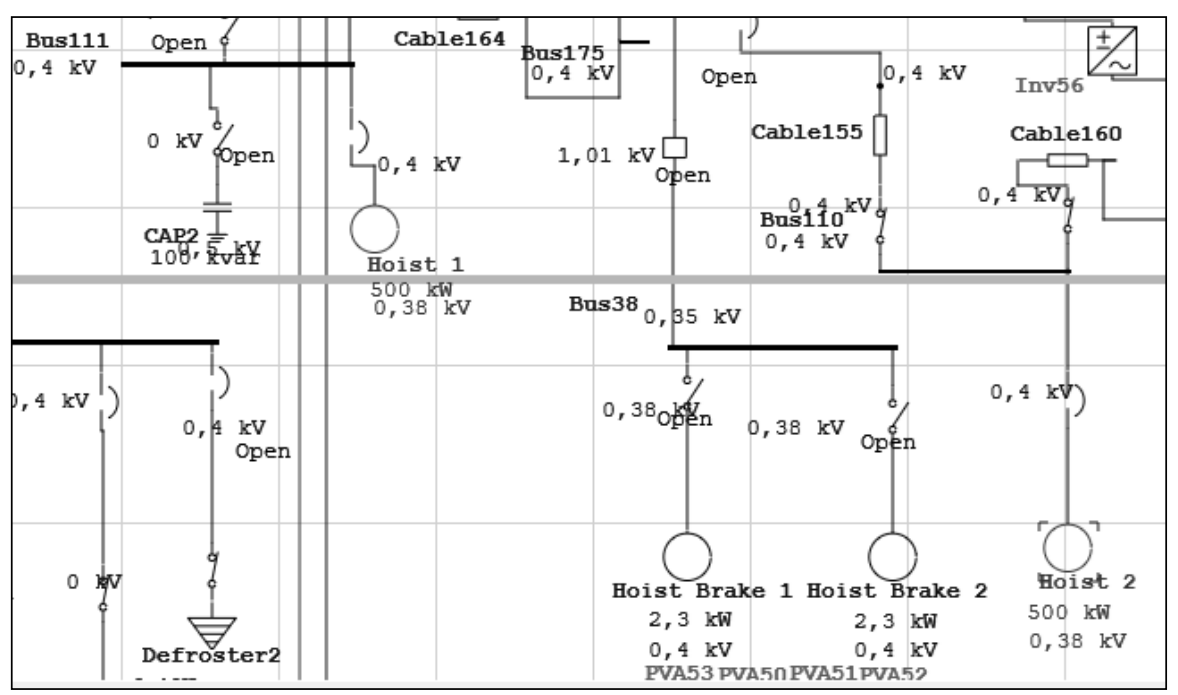

Figure. 9. Display of hoist motor of the container crane on the ETAP.

5. Trolley and Hoist Motor (Operated Simultaneously) In this fifth simulation, the trolley motor and the hoist motor run simultaneously. This step is made to search for the data generated when the two steps of the main motorbike are run simultaneously. As for the data on the specifications of the trolley motor and hoist motor, it has been mentioned in the scenario points above before.

The display of the trolley motor and hoist motor on the ETAP has been shown in the figure in the previous scenario.

\section{ANALYSIS OF RESULTS AND DISCUSSION}

1. Scenario 1 (Gantry motor) a. Load Flow Comparison

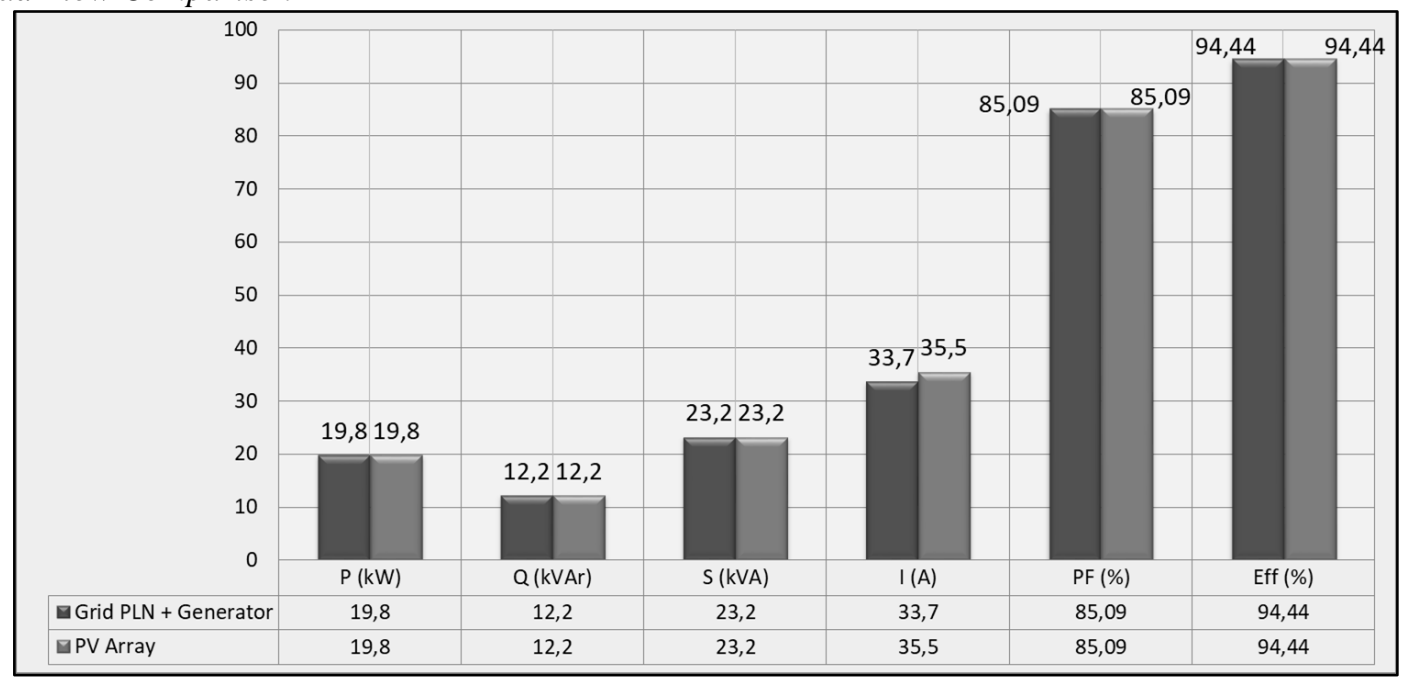

Figure. 10. Gantry motor load flow comparison.

In Figure 10, it can be seen that either using the supply from the PLN + generator grid, or the supply from the PV Array displays the power flow value data that is not much different. This is due to the inverter output of each type of supply (Inv14 and Inv49).

For the grid supply PLN + Generator, input data voltage $400 \mathrm{~V}$ (according to specifications and distribution bus for each motor). As for the PV Array supply, $380 \mathrm{~V}$ voltage output data is input (according to the Inverter specification).
So, even though the two power outputs are the same, this results in a difference in the current flowing to the motor for each type of supply. For grid supply, the PLN + Generator has a current (I) of 33.7 Ampere, and for the supply of PV Array has a current (I) of 35.5 Ampere. The difference between the currents of both reaches 1.8 Ampere, which results in the supply of PV Array, and with the same cable can make the cable heat up a little faster. 
b. Voltage Drop Values Comparison

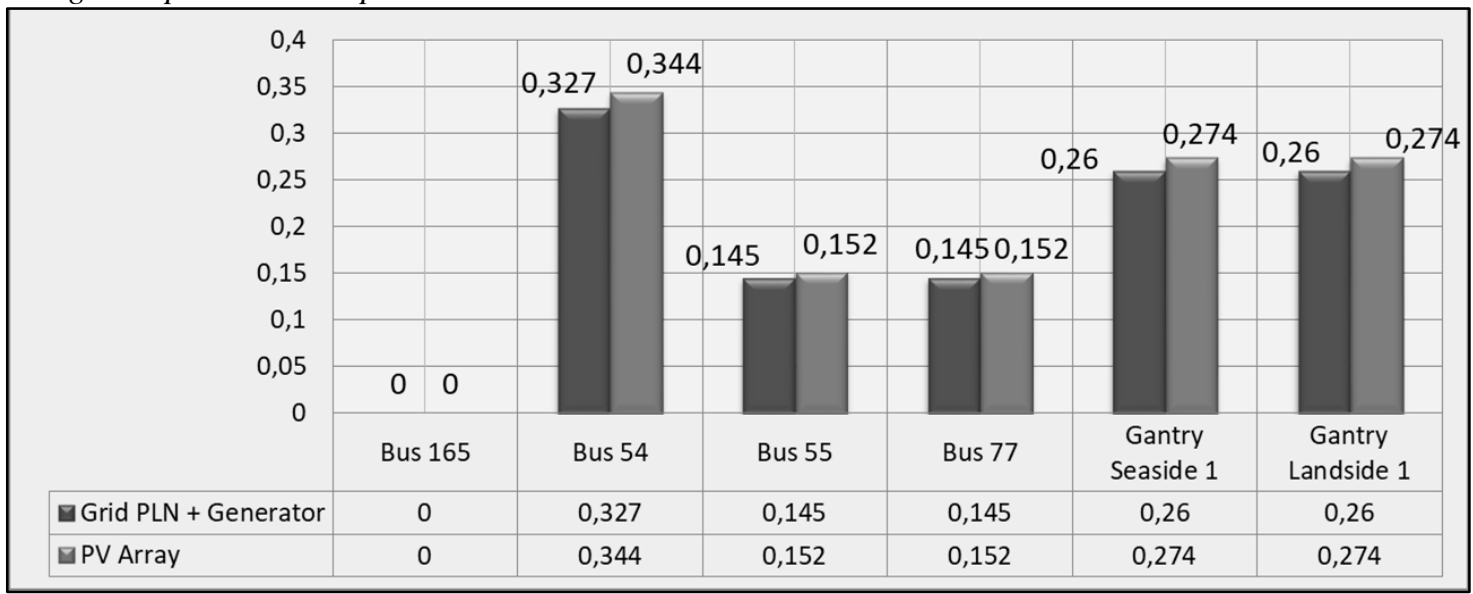

Figure. 11. Gantry motor voltage drop value comparison.

In Figure 11, the value of the voltage drop during the distribution to the motor gantry load is shown.

The voltage drop is caused by the installation of cables on each transmission line. With the same cross-sectional area and type of cable. the percentage value of the voltage drop from the grid supply PLN + Generator has a value smaller than the percentage of voltage drop from the PV Array. This is because the current flowing in the PV system is also greater than PLN + Generator. With the same power, the amount of voltage distributed is directly proportional to the current flowing in the cable.

c. Voltage Distribution Values for Each Bus Comparison

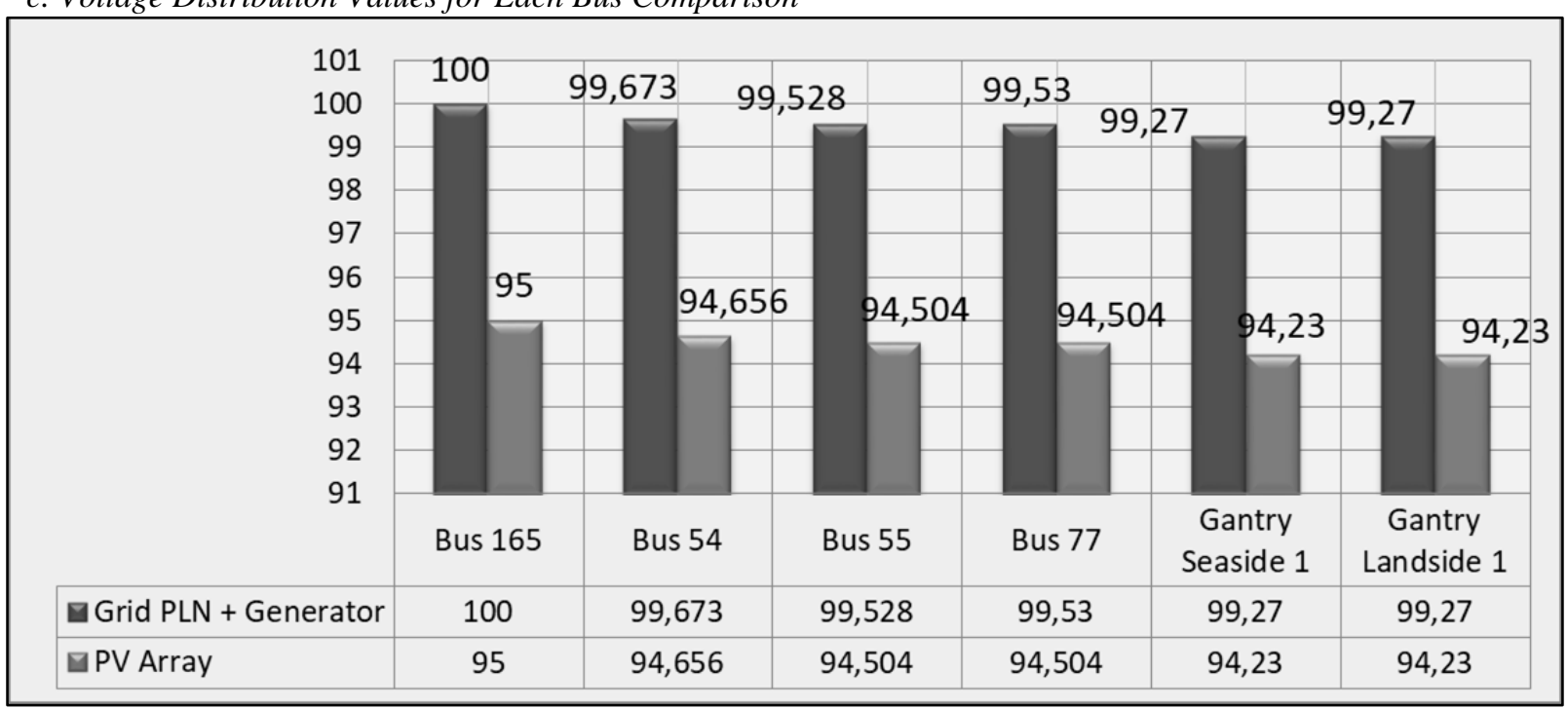

Figure. 12. Gantry motor voltage distribution comparison.

In Figure 12, the value of the voltage distribution for each bus on the PV Array supply is 5\% different from the voltage from the PLN + Generator grid supply. This is because the output voltage on the PV Array inverter is lower than the grid supply voltage from the PLN +
Generator. The decrease in the amount of voltage distribution in each type of supply occurs due to the installation of cables along the distribution line to the load of the gantry motor.

\section{Scenario 2 (Boom motor)}


a. Load Flow Comparison

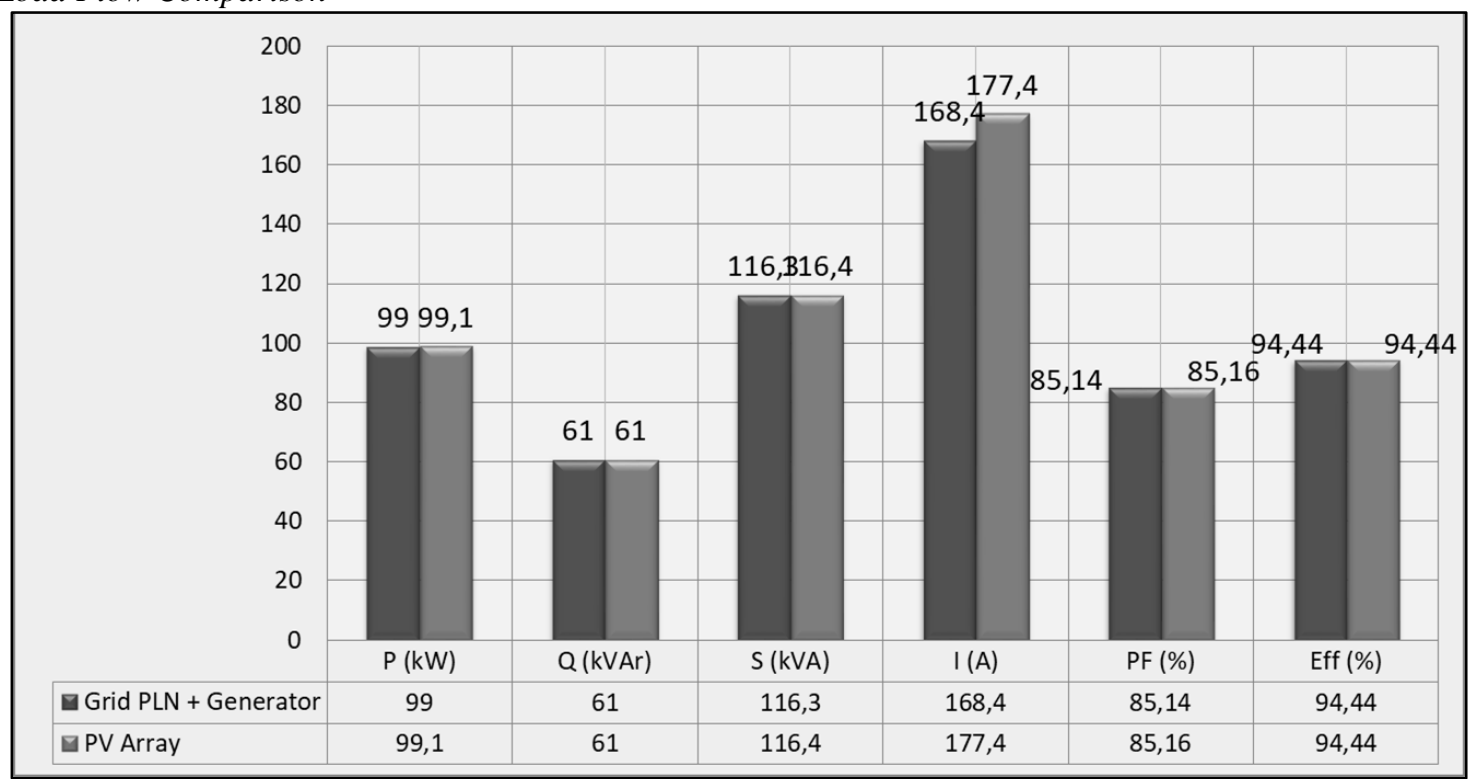

Figure. 13. Boom motor load flow comparison.

In Figure 13, it can be seen that both using the supply from the PLN + Generator grid, and the supply from the PV Array display the power flow value data that is not much different. This is due to the inverter output of each type of supply (Inv52 and Inv54).

For the grid supply PLN + Generator, input data voltage $400 \mathrm{~V}$ (according to specifications and distribution bus for each motor). As for the PV Array supply, $380 \mathrm{~V}$ voltage output data is input (according to the Inverter specification).

b. Voltage Drop Values Comparison
So, even though the two power outputs are the same, this results in a difference in the current flowing to the motor for each type of supply. In the Boom motor simulation, the PLN + Generator grid supply has a current (I) of 168.4 Amperes, and for the PV Array supply a current (I) of 177.4 Amperes. The difference in current reaches 9 Amperes, which results in the supply of PV Array, and with the same cable, it can make the cable heat up a little faster.

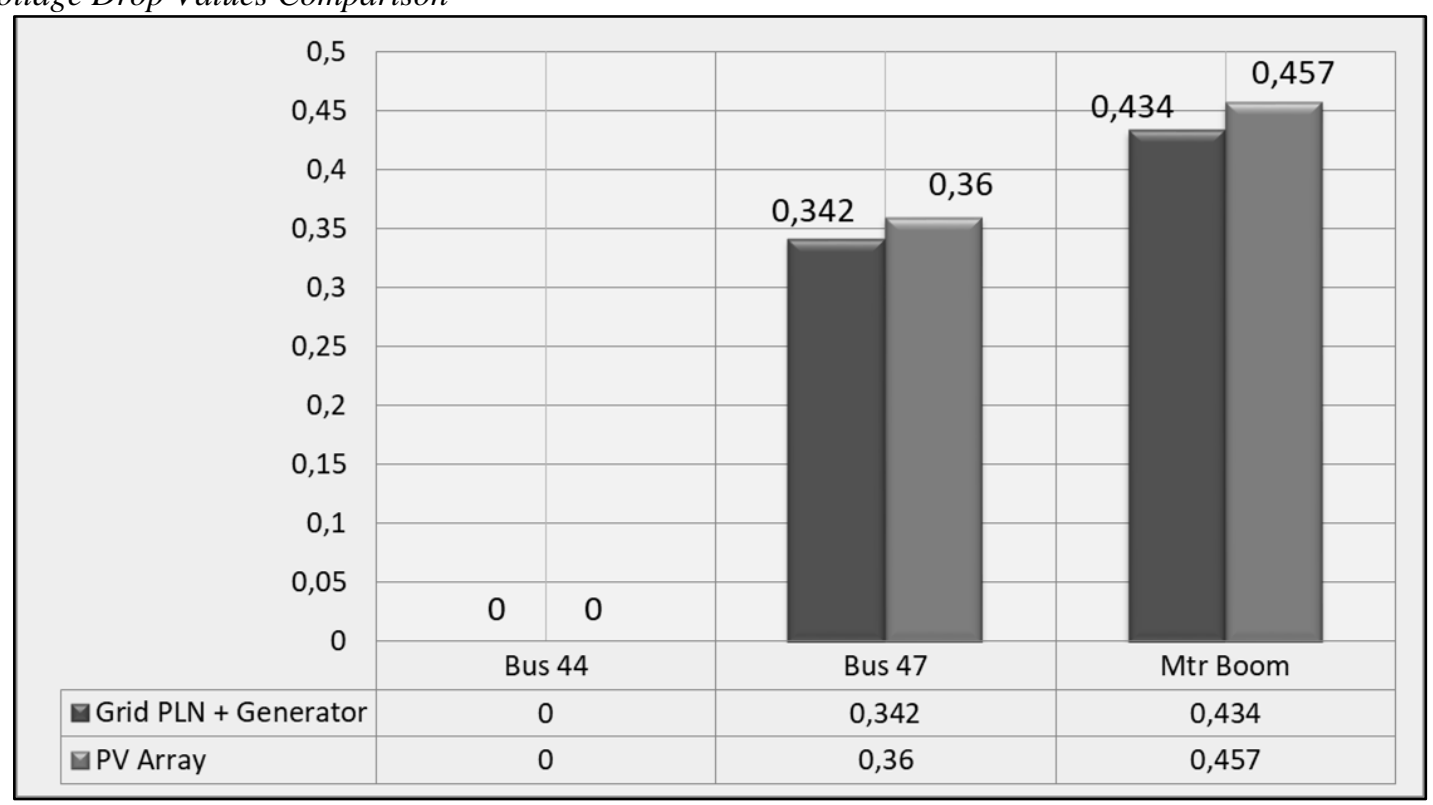

Figure. 14. Boom motor voltage drop value comparison.

In Figure 14, the value of the voltage drop or drop during distribution to the boom motor load is displayed. The voltage drop is caused by the installation of cables on each transmission line. With the same cross-sectional area and type of cable. the percentage value of the voltage drop from the grid supply PLN + Generator has a value smaller than the percentage of voltage drop from the PV Array. This is because the current flowing in the PV system is also greater than PLN + Generator $(0.434 \%$ with $0.457 \%$ ). With the same power, the amount of voltage distributed is directly proportional to the current flowing in the cable. 
c. Voltage Distribution Values for Each Bus Comparison

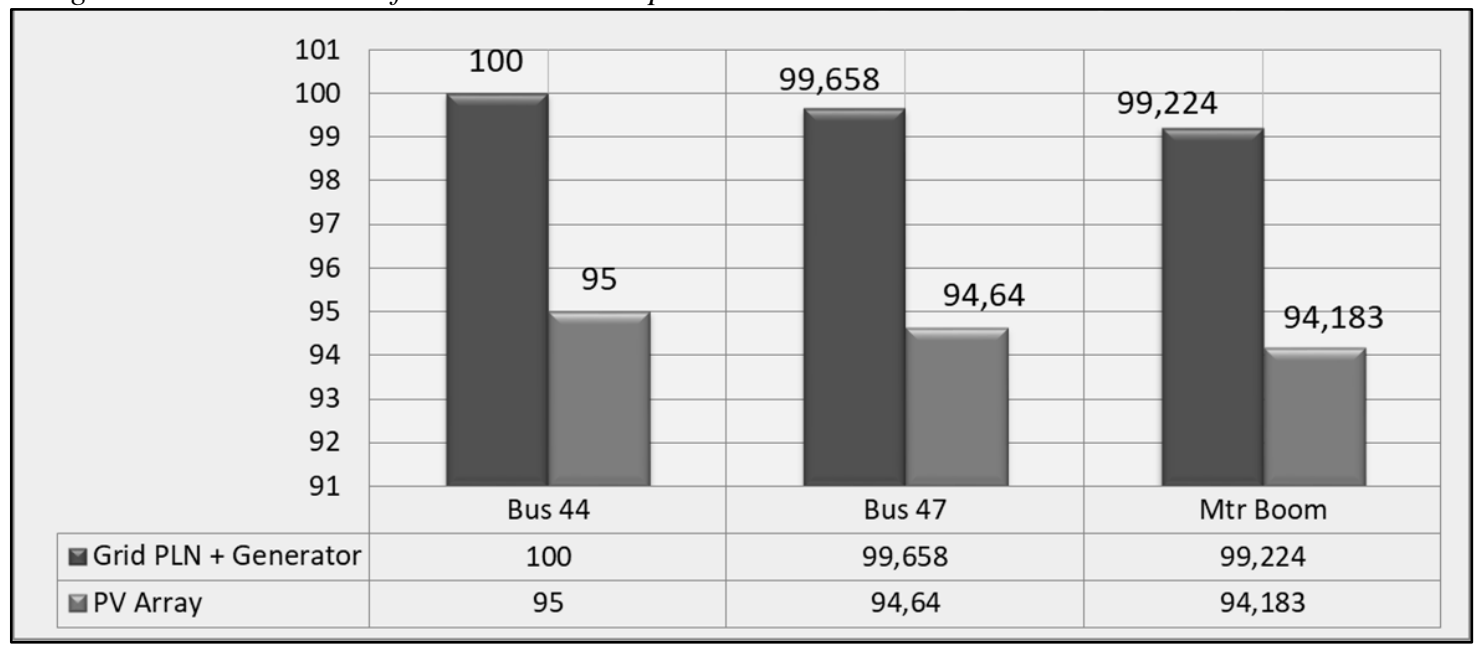

Figure. 15. Boom motor voltage distribution comparison.

In Figure 15, the voltage distribution value for each bus on the PV Array supply is 5\% different from the voltage from the PLN + Generator grid supply. This is because the output voltage on the PV Array inverter is lower than the grid supply voltage from the PLN + Generator. The decrease in the amount of voltage distribution in each type of supply, to be as shown in the figure $(99.224 \%$ and $94.183 \%$ ), occurred due to the installation of cables along the distribution line to the boom motor load.

\section{Scenario 3 (Trolley motor)}

a. Load Flow Comparison

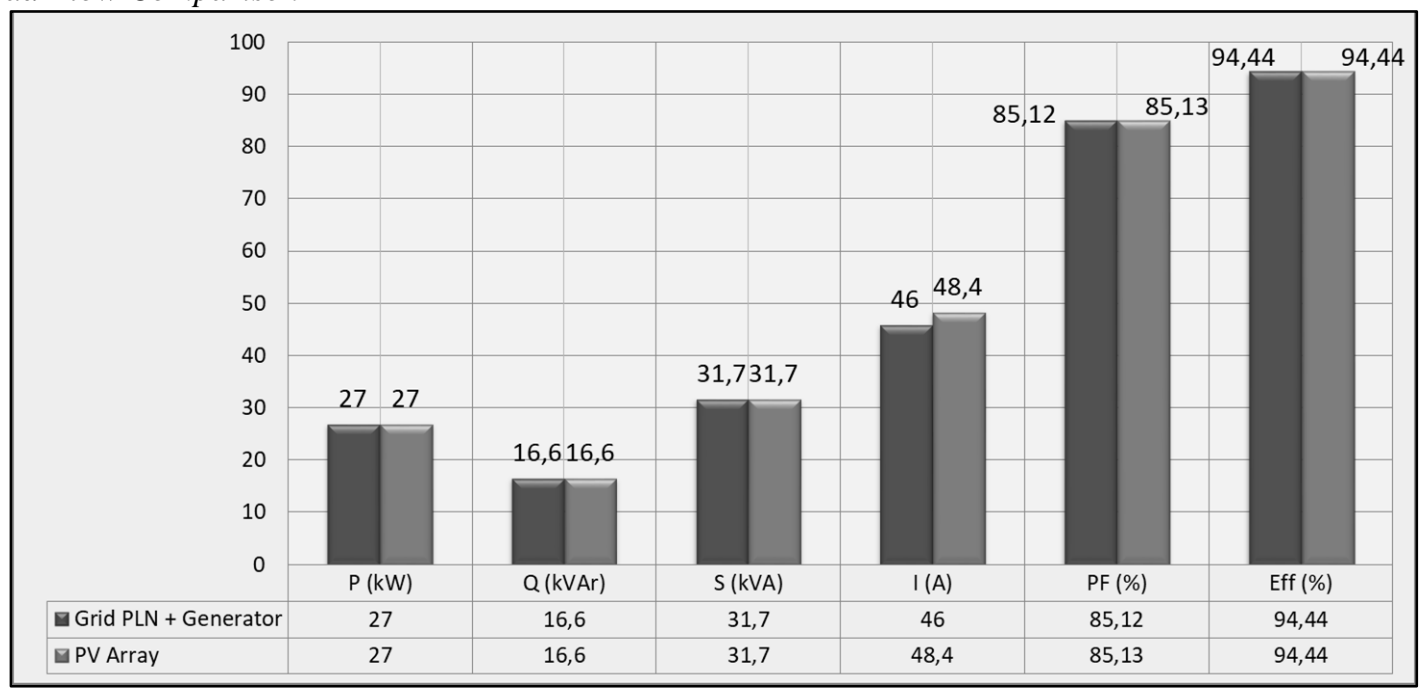

Figure. 13. Trolley motor load flow comparison.

In Figure 16, it can be seen that both using the supply from the PLN + Generator grid, and the supply from the PV Array display the power flow value data that is not much different. This is due to the inverter output of each type of supply (Inv52 and Inv54).

For the grid supply PLN + Generator, input data voltage $400 \mathrm{~V}$ (according to specifications and distribution bus for each motor). As for the PV Array supply, $380 \mathrm{~V}$ voltage output data is input (according to the Inverter specification).
So, even though the two power outputs are the same, this results in a difference in the current flowing to the motor for each type of supply. In the Trolley motor simulation, the PLN + Generator grid supply has a current (I) of 46 Ampere, and for the PV Array supply a current (I) of 48.4 Ampere. The difference in current reaches 9 Amperes, which results in the supply of PV Array, and with the same cable, it can make the cable heat up a little faster. 
b. Voltage Drop Values Comparison

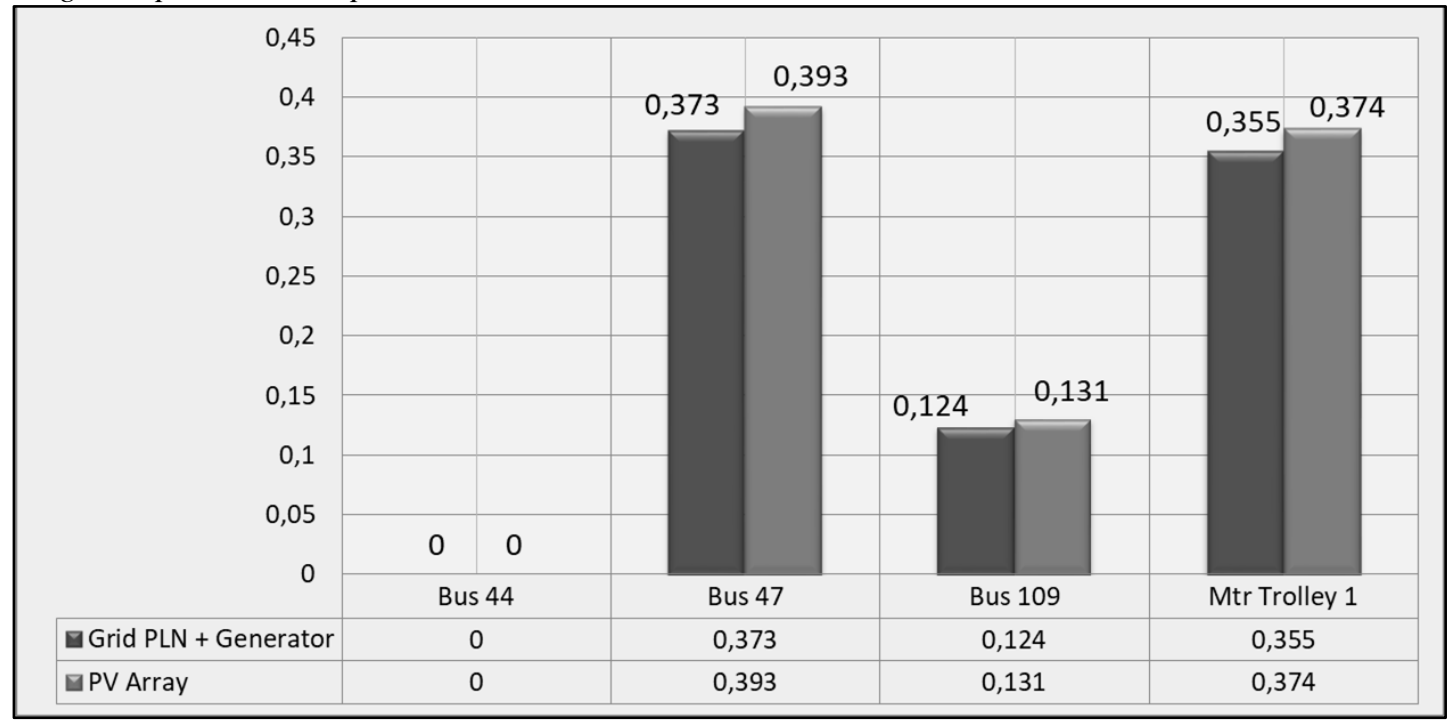

Figure. 17. Trolley motor voltage drop value comparison.

In Figure 17, the value of the voltage drop or drop during distribution to the motor trolley load is shown.

The voltage drop is caused by the installation of cables on each transmission line. With the same cross-sectional area and type of cable. the percentage value of the voltage drop from the grid supply PLN + Generator has a value smaller than the percentage of voltage drop from the PV Array. This is because the current flowing in the PV system is also greater than PLN + Generator $(0.355 \%$ with $0.374 \%$ ). With the same power, the amount of voltage distributed is directly proportional to the current flowing in the cable.

c. Voltage Distribution Values for Each Bus Comparison

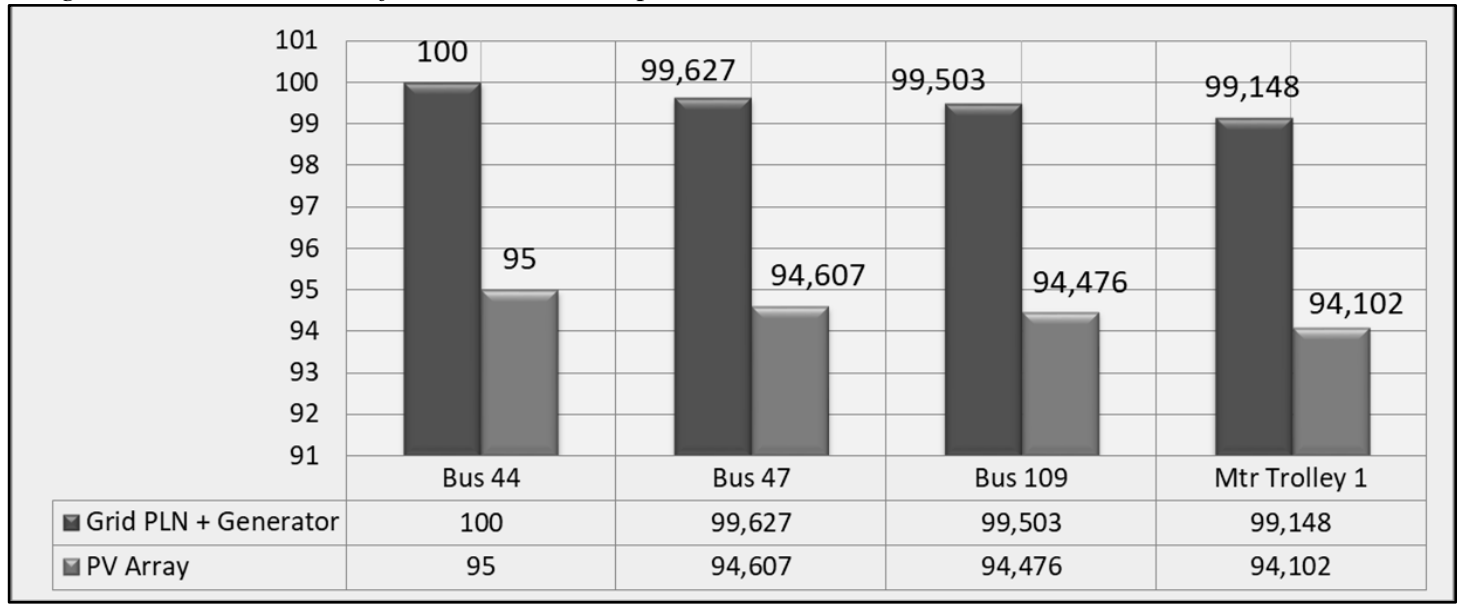

Figure. 18. Trolley motor voltage distribution comparison.

In Figure 18, the voltage distribution value for each bus on the PV Array supply is a 5\% difference from the voltage from the PLN + Generator grid supply. This is because the output voltage on the PV Array inverter is lower than the grid supply voltage from the PLN +
Generator. The decrease in the amount of voltage distribution in each type of supply, to the size of what is shown on the graph (99.148\% and $94.102 \%)$, occurs due to the installation of cables along the distribution line to the load of the Trolley motor.

\section{Scenario 4 (Hoist motor)}

a. Load Flow Comparison 


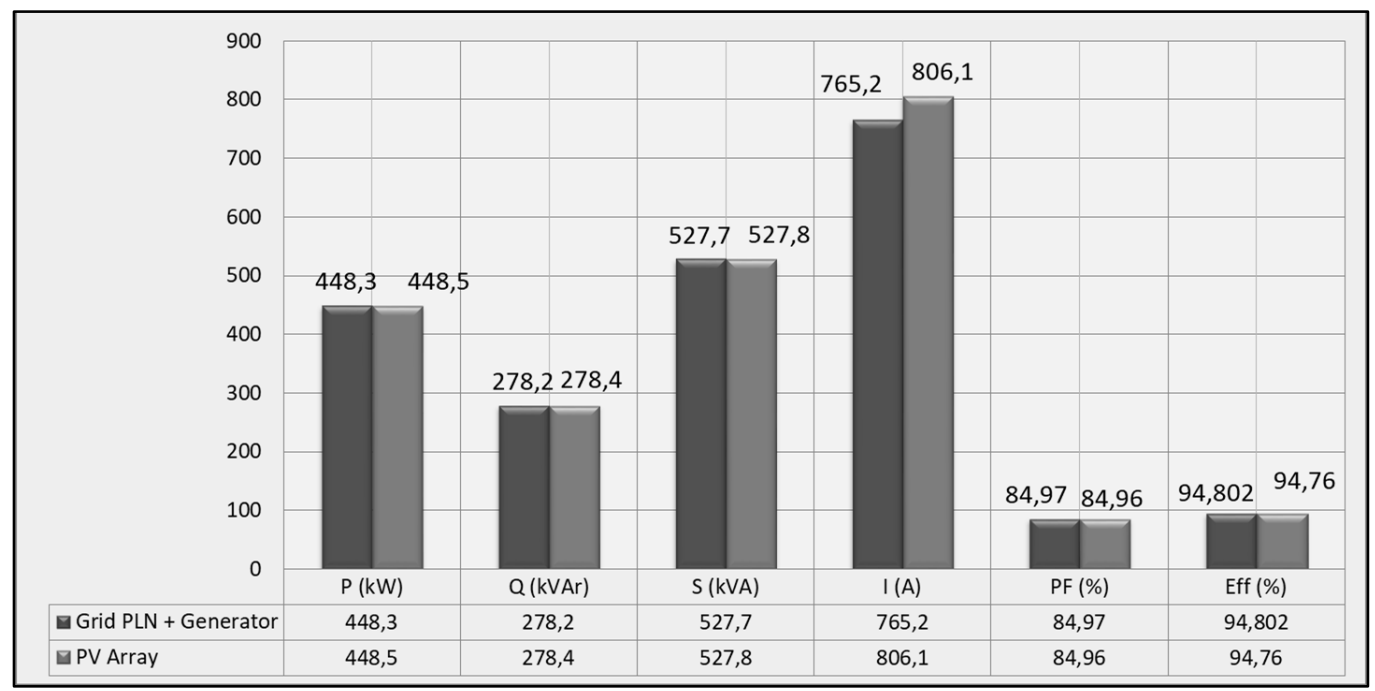

Figure 19. Hoist motor load flow comparison.

In Figure 19, it can be seen that both using the supply from the PLN + Generator grid, and the supply from the PV Array display the power flow value data that is not much different. This is due to the inverter output from each type of supply (Inv10 and Inv11 for the PLN + Generator grid, and Inv56 and Inv58 for PV Array).

For the grid supply PLN + Generator, input data voltage $400 \mathrm{~V}$ (according to specifications and distribution bus for each motor). As for the PV Array supply, $380 \mathrm{~V}$ voltage output data is input (according to the Inverter specification).
So, even though the two power outputs are the same, this results in a difference in the current flowing to the motor for each type of supply. In the Hoist motor simulation, the PLN + Generator grid supply has a current (I) of 765.2 Ampere, and for the PV Array supply, the current (I) is 806.1 Ampere. The difference in current reaches 40.9 Amperes, which results in the supply of PV Array, and with the same cable it can make the cable heat up a little faster.

\section{b. Voltage Drop Values Comparison}

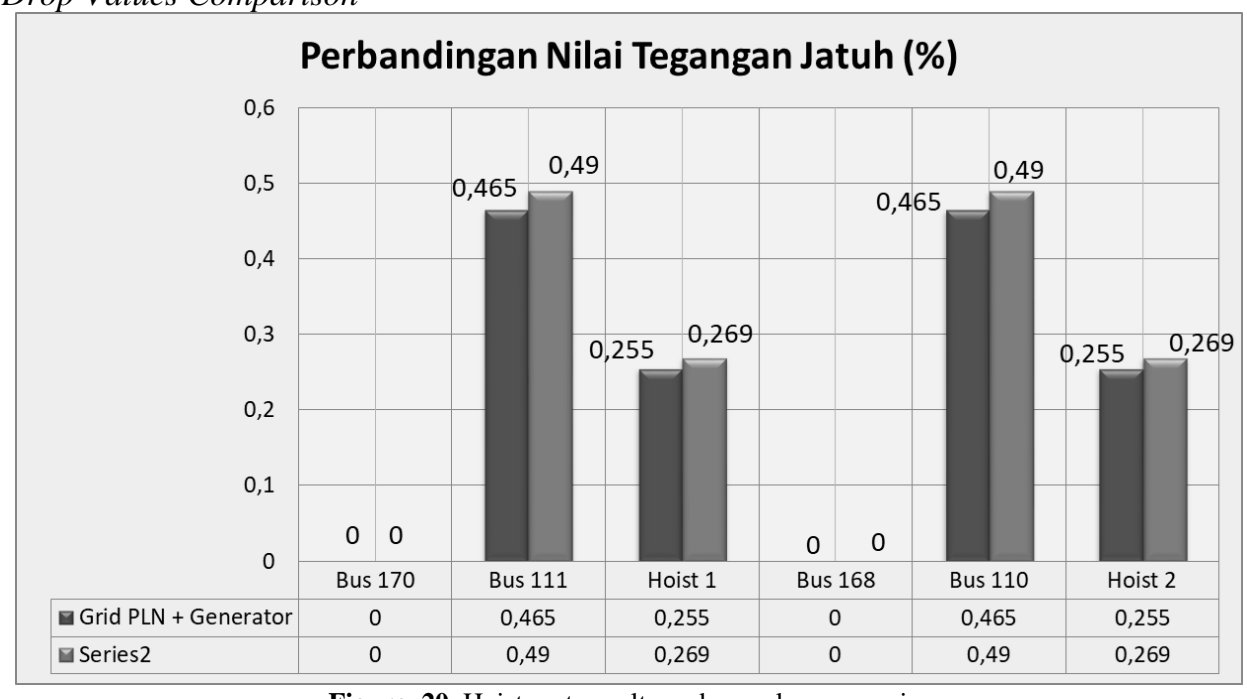

Figure. 20. Hoist motor voltage drop value comparison.

In Figure 20, the value of the voltage drop or drop during the distribution to the Hoist motor load is shown.

The voltage drop is caused by the installation of cables on each transmission line. With the same cross-sectional area and type of cable. the percentage value of the voltage drop from the grid supply PLN + Generator has a value smaller than the percentage of voltage drop from the PV Array. This is because the current flowing in the PV system is also greater than PLN + Generator $(0.255 \%$ with $0.269 \%$ ). With the same power, the amount of voltage distributed is directly proportional to the current flowing in the cable. 
c. Voltage Distribution Values for Each Bus Comparison

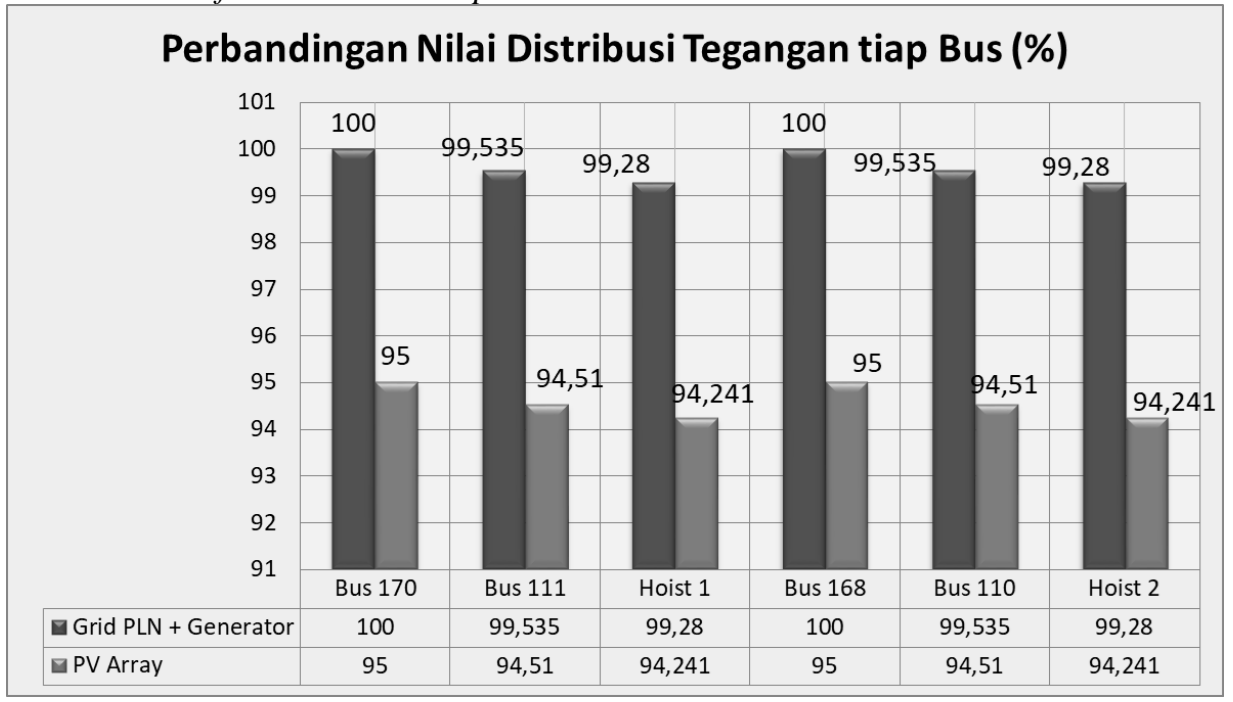

Figure. 21. Hoist motor voltage distribution comparison.

In Figure 21, the value of the voltage distribution for each bus on the PV Array supply is 5\% different from the voltage from the PLN + Generator grid supply. This is because the output voltage on the PV Array inverter is lower than the grid supply voltage from the PLN +

\section{Total Power Requirements}

The total power requirements for each main motor step are different, according to the existing specifications for each container crane motor.

For gantry motors, there are 8 seaside gantry motors and 8 landside gantry motors with output power specifications of $22 \mathrm{~kW}$ each. With a demand factor of $85 \%$, each output power is only $18.7 \mathrm{~kW}$. Then the total power requirement of the gantry motor is $18.7 \mathrm{~kW} \times 16$ $=352 \mathrm{~kW}$. Meanwhile, in Table 4.3, each gantry motor

has a motor input power of $19.8 \mathrm{~kW}$. So that the total input power supply becomes $19.8 \times 16=317.2 \mathrm{~kW}$.

For the boom motor, there is only 1 boom motor, with an output power specification of $110 \mathrm{~kW}$. With a demand factor of $85 \%$, the output power is only $93.5 \mathrm{~kW}$. Then the total requirement is $93.5 \mathrm{~kW}$. Meanwhile, in Table

\section{CONCLUSIONS}

\section{Conclusion}

(a) The simulation results with the solar panel supply from the ETAP PV Array, from all the scenarios that have been tried, it produces several different power flow values. Whether it's an active power, or power efficiency, to the power loss contained in the system. In scenario 1 (motor gantry) has a power loss value of 1.1 $\mathrm{kW}$ with a power efficiency of $94.44 \%$. The voltage drop on the motor is $0.274 \%$. In scenario 2 (boom motor) has a power loss value of $5.6 \mathrm{~kW}$ with a power efficiency of $94.4 \%$. The voltage drop on the motor is $0.457 \%$. In scenario 3 (motor trolley) has a power loss value of 2.5 $\mathrm{kW}$ with a power efficiency of $94.44 \%$. The voltage drop
Generator. The decrease in the amount of voltage distribution in each type of supply, to the size of what is shown on the graph (99.28\% and $94.241 \%)$, occurs due to the installation of cables along the distribution line to the load of the Hoist motor.

4.9 , the boom motor has a motor input power of $99 \mathrm{~kW}$. So that the total input power supply $=99 \mathrm{~kW}$.

For the motor trolley, there are 4 trolley motors with an output power specification of $30 \mathrm{~kW}$ each. With a demand factor of $85 \%$, each output power is only 25.5 $\mathrm{kW}$. Then the total power requirement of the gantry motor is, $25.5 \mathrm{~kW} \times 4=102 \mathrm{~kW}$. Meanwhile, in Table 4.15 , each motor trolley has a motor input power of 27 $\mathrm{kW}$. So that the total input power supply becomes $27 \times 4$ $=108 \mathrm{~kW}$.

For hoist, there are 2 hoist motors with an output power specification of $500 \mathrm{~kW}$ each. With a demand factor of $85 \%$, each output power is only $425 \mathrm{~kW}$.

However, due to the placement between the hoist motors on different buses, the total hoist motor power requirements are the same as their respective needs, namely $425 \mathrm{~kW}$. Meanwhile, in Table 4:21, each hoist motor has a motor input power of $448.3 \mathrm{~kW}$. However, due to the placement between the hoist motors on different buses, the total input power supply is equal to $448.3 \mathrm{~kW}$.

on the motor is $0.374 \%$. In scenario 4 (hoist motor) has a power loss value of $23.5 \mathrm{~kW}$ with a power efficiency of $94.76 \%$. The voltage drop on the motor is $0.269 \%$.

(b) The simulation using a PV Array supply produces output, both power, and voltage, which is always lower in value than the PLN + Generator supply. The difference is always between $5 \%$ because PV produces a voltage of 380 Volts, PLN + Generator at 400 Volts. Even so, the PV supply still meets the prevailing standards. The PV supply for power efficiency is still $\geq 50 \%$, within the minimum limit of the IEEE. Meanwhile, the PV supply for dropping voltages also still enters the IEC standard $\leq 5 \%$. The comparison between PV Array and PLN + Generator produces a power flow that is not much different. The bigger difference is in the current flowing in the system. In a PV 
supply circuit, with the same wire, it generates a higher current in each scenario. This is because the PV voltage is lower while the power required by the motor is constant.

(c) In scenario 5 simulation, the trolley and hoist motors have been analyzed, such as the working steps of each motor. In that sense, the motors can work independently and do not affect each other because they are located on different distribution buses on the ETAP or on a one-line diagram of a container crane.

\section{Recommendations}

In this study of the power flow on container crane based on ETAP simulation, several problems occur, such as during modeling, simulation, and data collection. Therefore, here are some recommendations that can be considered and considered for this further research, including:

\section{REFERENCES}

[1] Hutagalung, B. R. 2004. Dampak Aktivitas Pelabuhan dan Sebaran Pencemaran Lingkungan Pelabuhan Tanjung Emas Semarang dan Kawasan Sekitarnya. Universitas Diponegoro.

[2] Asshanti, F., Masroeri, A., A. 2017. Analisa Kebutuhan Daya Listrik Container Crane Dalam Rangka Elektrifikasi Container Crane Untuk Mengoptimalkan Proses Bongkar Muat Di Terminal Petikemas Surabaya. Institut Teknologi Sepuluh Nopember.

[3] Catur, R., Sarwito, S. 2019. Studi Aliran Daya pada Kapal Dynamic Positioning Dalam Berbasis Skala Laboratorium. Institut Teknologi Sepuluh Nopember.

[4] IEEE Standards Associations. The IEEE Standards.

[5] Iqbal, M., Sarwito, S., Kusuma, I. R. 2011. Analisa Kapasitas Daya Listrik Container Crane untuk Optimalisasi Proses Bongkar Muat. Institut Teknologi Sepuluh Nopember.

[6] Multa, L., Aridani. P. R. 2013. Modul Pelatihan ETAP 7.0.0. Universitas Gadjah Mada Saragi, S. H., Yuningtyastuti. (2012).

[7] Sistem Operasi Container Crane (CC) di Terminal Peti Kemas Semarang. Universitas Diponegoro

[8] Salman, R., Mustamam., Sinuraya. A. 2015. Simulasi dan Analisis Aliran Daya pada Sistem Tenaga Listrik Menggunakan Perangkat Lunak Electrical Transient Analyser Program (ETAP) versi 4.0 .

[9] Stevenson, D. W. 2000. Analisis Sistem Tenaga Listrik. Erlangga

[10] Wijoyo, S. Y., Halim. F. A. 2018. Analisis Pemasangan Rooftop Photovoltaic System pada Sistem Elektrikal Bangunan. Universitas Gadjah Mada

[11] Adhiguna, B., Yandri., Khwee. 2018. Analisis Tekno Ekonomi Perbandingan Quay Container Crane (QCC) no. 03 dengan Sumber Energi dari Genset dan no. 04 dengan Sumber Energi PLN

[12] Elton, S., Sarwito, S., Kurniawan, A. 2017. Analisa Teknis dan Ekonomis Automatic Stacking Crane di PT. Terminal Teluk Lamong PELINDO III. Institut Teknologi Sepuluh Nopember.

[13] Sarwito, Sardono \& Semin, Semin \& Zaman, Muhammad. (2019). Short Circuit Study on Closed Circuit Electrical System of Ship Dynamic Positioning System based on Laboratory Scale Experiment.

[14] Kusuma, I. R., Sarwito, S., Sanuri, S., Zaman, M. B., \& P, A. P. P. (2019). Analisa Drop Voltage dan Short Circuit pada Kapal Trimaran 1. 1-4.

[15] Sarwito, Sardono, Kurniawan, Adi, Wahyudy, F. R. (2016). Analisa Arus Starting Transformator Pada Pengoperasian (a) When there is a willingness to continue researching the flow of power on this container crane object, they should try using another simulation application whenever possible.

(b) It is advisable to model the supply of solar panels for electric motors experimentally. As well as considering the economic aspects and allocation of PV Array placement in the field.

(c) Before conducting simulations or experimental practices, it is better to complete the specifications of each component of the electrical system, such as cables, motors, inverters, circuit breakers, generators, transformers, and so on, in order to get more accurate data.

(d). If there are additions, it can be included in scenario 5 which in this study cannot be analyzed, to become a new topic of discussion. Be it a trolley + boom or another step motor that runs simultaneously.

Container Crane Di Pelabuhan. Sepuluh Nopember Institute of Technology.

[16] Sarwito, Sardono, Kurniawan, Adi, Wahyudianto, M. F. (2016) Analisa Tegangan Jatuh Pada Sistem Distribusi Listrik Di Km. Dorolonda Dengan Menggunakan Simulasi Electrical Transient Analysis Program (ETAP). Sepuluh Nopember Institute of Technology. 